\title{
Effect of Surface Fertigation on Nutrient Uptake, Fertilizer Use Efficiency and Economics of Inter - Specific Hybrid Bt Cotton
}

\author{
Bharath Raj H. R* , Mukund Joshi, Vishaka G. V \\ Department of Agronomy, University of Agricultural Sciences, Bangalore
}

Copyright (C) 2015 Horizon Research Publishing All rights reserved.

\begin{abstract}
A field investigation on Effect of surface fertigation on nutrient removal, fertilizer use efficiency and economics of inter-specific hybrid $B t$ cotton was carried out at agronomy field unit, UAS, GKVK, Bangalore during kharif 2012. The experiment was laid out in randomized complete block design with 7 treatments and 3 replications involving treatment combinations of 3 splits $\left(\mathrm{T}_{2}\right.$ and $\left.\mathrm{T}_{3}\right), 4$ splits $\left(\mathrm{T}_{4}\right.$ and $\left.\mathrm{T}_{5}\right)$ and 5 splits $\left(\mathrm{T}_{6}\right.$ and $\left.\mathrm{T}_{7}\right)$ at 75 and 100 per cent dosages of recommended dose fertilizer as compared to recommended dose of fertilizer through soil application. It was observed that significantly higher N, P and K uptake (160.99, 28.57 and $134.87 \mathrm{~kg} \mathrm{ha}^{-1}$, respectively) was recorded in 100 per cent recommended dose of fertilizer with fertigation in 5 splits. The higher nutrient uptake in fertigation treatments was attributed to higher fertilizer use efficiency and nutrient availability in the soil as compared to recommended dose of fertilizer through soil application. Among different treatments, application of 100 per cent recommended dose of fertilizer with fertigation in 5 splits recorded higher net returns (79231 Rs. ha ${ }^{-1}$ ) and $\mathrm{B}: \mathrm{C}$ ratio (3.41). It is advisable to adopt 5 splits application of all the major nutrients under surface fertigation to achieve higher cotton productivity and increasing $\mathrm{B}$ : $\mathrm{C}$ ratio, besides higher cost of cultivation.
\end{abstract}

Keywords Surface Fertigation, Fertilizer Use Efficiency, Nutrient Uptake, Recommended dose of fertilizer

\section{Introduction}

Cotton (Gossypium spp.) popularly known as "white gold", is an important commercial fibre crop grown under diverse agro-climatic conditions around the world. It provides fibre, an important raw material for textile industry. More than 70 per cent demand from Indian textile industries is met by cotton fibres. Even though, India ranks first with respect to area under cultivation, it stands third in total production after
USA and China. Fertigation has been found to increase the efficiency in the application of fertilizer besides reducing the quantity of fertilizes applied. This in turn, reduces the cost of production and also minimizes the ground water pollution thereby preventing ecological disturbances and health risks occurred due to leaching and accumulation of nitrates in the deeper layers. As such, use of fertigation could prove as a blessing for Indian farming may pave the way for efficient use of costly and scarce fertilizers. The fertigation technique is presently restricted to drip method of irrigation. In India, out of 633 lakh ha irrigated area only 4.5 lakh ha is under micro irrigation system and remaining area is under surface method of irrigation. The major limitation of drip irrigation is its higher initial investment. Applicability of fertigation technique in surface irrigation is more useful, as more irrigated area ( $>99$ per cent) is under surface methods. Adopting fertigation under drip method also calls for use of fully soluble fertilizers to avoid clogging due to undissolved part of fertilizers. High cost and non-availability of water soluble fertilizers are the other disadvantages of drip fertigation technology. But, conventional fertilizers could be easily used in fertigation with surface methods facilitating easy adoption by more farmers. The suitability of fertigation technique in surface method of irrigation by using conventional fertilizers needs to be studied in this direction.

\section{Material and Methods}

A field experiment on Cotton was conducted at ZARS, GKVK, Bengaluru (12 $51^{\prime} \mathrm{N}, 77^{\circ} 35^{\prime} \mathrm{E}$ and $930 \mathrm{~m}$ Above Mean Sea Level) during kharif season of 2012. The texture of soil was red sandy loam having neutral $\mathrm{pH}$ with organic carbon (0.52\%), available nitrogen (281.5 $\left.\mathrm{kg} \mathrm{ha}^{-1}\right)$, phosphorous (74.3 $\mathrm{kg} \mathrm{ha}^{-1}$ ), and potassium (198.08 $\mathrm{kg} \mathrm{ha}^{-1}$ ). The rainfall of $361.7 \mathrm{~mm}$ was received during cropping period. The daily mean maximum and minimum temperatures for the cropping period were $29.2^{\circ} \mathrm{C}$ and $16.2^{\circ}$ $\mathrm{C}$, respectively. The hybrid used was KDCHB-407 BG1. The experiment was laid out in a Randomized Complete Block Design with three replications involving 7 treatments 
viz., $\quad \mathbf{T}_{1}$ : $\mathrm{RDF}-$ soil application in $(1+2)$ splits $(50 \%+25 \%+25 \%) \mathbf{T}_{2}$ : Fertigation in 3 splits $(33 \%$ each) $100 \%$ dose of N, P, $\mathrm{K} \mathrm{T}_{3}$ : Fertigation in 3 splits $-75 \%$ dose of N, P, K T $\mathbf{T}_{4}$ : Fertigation in 4 splits (25\% each) - $100 \%$ dose of N, P, K T $\mathbf{T}_{5}$ : Fertigation in 4 splits $-75 \%$ dose of N, P, K $\mathbf{T}_{6}$ : Fertigation in 5 splits ( $20 \%$ each) $-100 \%$ dose of N, P, K $\mathbf{T}_{7}$ : Fertigation in 5 splits $-75 \%$ dose of N, P, K. The fertilizers) used in the experiment were urea, single super phosphate (SSP) and muriate of potash (MOP) as N, P and K sources, respectively. In both sets of $75 \%$ and $100 \%$ recommended dose, the surface fertigation was imposed using 3 splits, 4 splits and 5 splits respectively at 20, 40 and 60 DAS, 20, 40, 60 and 80 DAS and 20,40, 60, 80 and 100 DAS. For each fertigation event, the weighed quantity of fertilizer per plot was equally divided in 7 quantities. In each plot, specified equal quantities of fertilizers were placed at beginning of row and $1 \mathrm{~m}^{3}$ of water was supplied to each row at an average discharge of $5.4 \mathrm{lps}$. In every event of fertigation, the weighed quantity of fertilizers included urea, super phosphate and muriate of potash. Thus splits of all three major nutrients were achieved. (RDF- 150:75:75 N, $\mathrm{P}_{2} \mathrm{O}_{5}$ and $\mathrm{K}_{2} \mathrm{O}$ ). Fisher's method of analysis of variance was used for analysis and interpretation of data as given by Panse and Sukhatme (1967).

\section{Results and Discussion}

\section{Effect of surface fertigation on nutrient uptake by hybrid cotton}

Total nitrogen uptake at harvest was significantly higher with fertigation which received 100 per cent RDF with fertigation in 5 splits $\left(161.00 \mathrm{~kg} \mathrm{ha}^{-1}\right)$ over RDF-soil application and other fertigation treatments. Similar trend in the uptake of phosphorus $\left(28.57 \mathrm{~kg} \mathrm{ha}^{-1}\right)$ and potassium $\left(134.87 \mathrm{~kg} \mathrm{ha}^{-1}\right.$ ) was noticed (Table 1). In general, uptake of NPK in fertigation treatments was significantly superior over the soil application of fertilizer. The higher uptake in the fertigation treatment was the result of significantly higher dry weight production in different plant parts at harvest and there was no dilution of NPK as dry weight production increased. This increase in uptake was due to better availability of nutrients at root zone as a result of frequent application of nutrients at different intervals to ultimately reduce losses. These findings are in conformity with the reports of Nalayini et al. (2001) and Srinivasan (2003)

\section{Effect of drip fertigation on fertilizer use efficiency by hybrid cotton}

Fertilizer use efficiency was also significantly superior in fertigation treatments which received 75 per cent and 100 per cent of NPK at 5 splits (4.06 and 3.69, respectively) (Table 2) over other fertigation treatments and RDF-soil application. Higher fertilizer use efficiency was due to better availability of moisture and nutrients in sufficient quantity throughout the growth stages in more splits with fertigation leading to better uptake of nutrients and production in seed cotton. Lower fertilizer use efficiency in soil application of nutrients can also be related to higher losses of mobile elements such as $\mathrm{N}$ and $\mathrm{K}$ from the root zone. Higher fertilizer use efficiency with fertigation was also reported by Balasubramanian et al. (2000)..

Table 1. Nutrient uptake (NPK) at harvest $\left(\mathrm{kg} \mathrm{ha}^{-1}\right)$ as influenced by surface fertigation with different splits and dosage of fertilizer in hybrid $B t$ cotton

\begin{tabular}{|c|c|c|c|}
\hline \multirow{2}{*}{ Treatments } & \multicolumn{3}{|c|}{$\left(\right.$ Uptake kg ha $\left.^{-1}\right)$} \\
\hline & Nitrogen & Phosphorus & Potassium \\
\hline $\mathrm{T}_{1}:$ RDF-Soil application & 99.70 & 18.54 & 80.96 \\
\hline $\mathrm{T}_{2}$ : Fertigation in 3 splits- $100 \%$ dose & 131.82 & 25.12 & 110.44 \\
\hline $\mathrm{T}_{3}:$ Fertigation in 3 splits- $75 \%$ dose & 110.79 & 21.19 & 93.00 \\
\hline $\mathrm{T}_{4}$ : Fertigation in 4 splits- $100 \%$ dose & 139.00 & 26.44 & 116.66 \\
\hline $\mathrm{T}_{5}:$ Fertigation in 4 splits- $75 \%$ dose & 115.01 & 21.95 & 96.11 \\
\hline $\mathrm{T}_{6}$ : Fertigation in 5 splits- $100 \%$ dose & 160.99 & 28.57 & 134.87 \\
\hline $\mathrm{T}_{7}:$ Fertigation in 5 splits- $75 \%$ dose & 134.87 & 25.75 & 112.80 \\
\hline S.Em \pm & 5.53 & 1.06 & 4.66 \\
\hline C.D. at $5 \%$ & 17.05 & 3.27 & 14.37 \\
\hline
\end{tabular}

Table 2. Fertilizer use efficiency and Economics of hybrid $B t$ cotton production as influenced by surface fertigation with different splits and dosage of fertilizer

\begin{tabular}{|c|c|c|c|c|}
\hline \multirow[b]{2}{*}{ Treatments } & \multirow{2}{*}{$\begin{array}{c}\text { Fertilizer use } \\
\text { efficiency } \\
\left(\mathrm{Kg}^{-k^{-1}}\right)\end{array}$} & \multicolumn{3}{|c|}{ Economics } \\
\hline & & $\begin{array}{c}\text { Gross returns } \\
\left(\text { Rs. ha }^{-1}\right)\end{array}$ & $\begin{array}{l}\text { Net returns } \\
\left(\text { Rs. ha }^{-1}\right)\end{array}$ & B:C Ratio \\
\hline $\mathrm{T}_{1}$ : RDF-Soil application & 2.02 & 61347 & 31703 & 2.06 \\
\hline $\mathrm{T}_{2}$ : Fertigation in 3 splits- $100 \%$ dose & 2.97 & 90156 & 58912 & 2.88 \\
\hline $\mathrm{T}_{3}$ : Fertigation in 3 splits $-75 \%$ dose & 3.19 & 72534 & 43256 & 2.47 \\
\hline $\mathrm{T}_{4}$ : Fertigation in 4 splits- $100 \%$ dose & 3.11 & 94281 & 62244 & 2.94 \\
\hline $\mathrm{T}_{5}$ : Fertigation in 4 splits- $75 \%$ dose & 3.35 & 76197 & 46126 & 2.53 \\
\hline $\mathrm{T}_{6}$ : Fertigation in 5 splits- $100 \%$ dose & 3.69 & 112101 & 79231 & 3.41 \\
\hline $\mathrm{T}_{7}$ : Fertigation in 5 splits- $75 \%$ dose & 4.06 & 92466 & 61562 & 2.99 \\
\hline
\end{tabular}



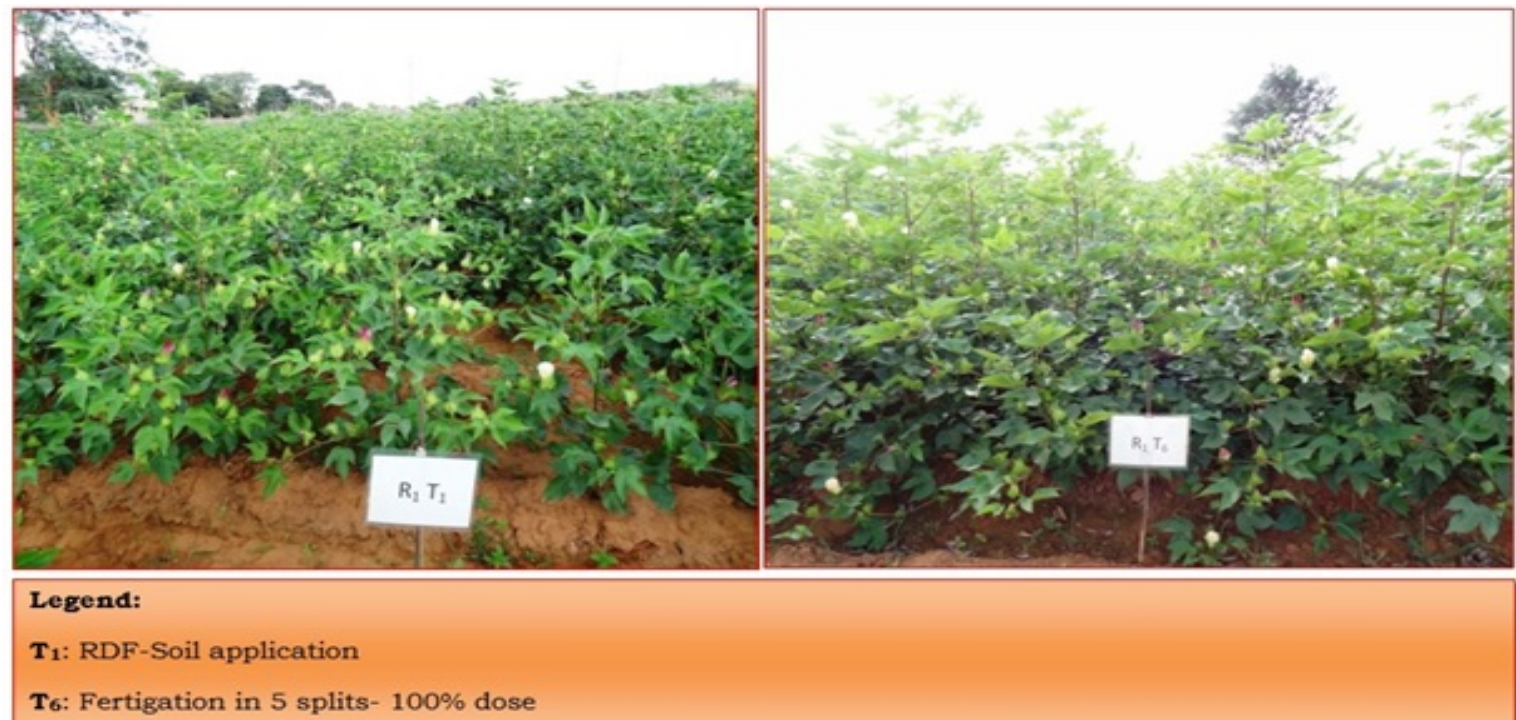

Plate I : Difference in growth of hybrid cotton as influenced by $T_{1}$ and $T_{6}$ treatments.

\section{Economics}

Fertigation of 100 per cent recommended NPK resulted in higher cost of cultivation, whereas, 75 per cent recommended NPK fertigation treatments and RDF-soil application resulted in lower cost of cultivation. This was due to increased cost of cultivation in more splits of fertigation treatments and with more fertilizer application compared to less splits of fertigation and reduced fertilizers compared to RDF-soil application. But, higher gross returns (112101 Rs. ha ${ }^{-1}$ ), net returns (79231 Rs. ha ${ }^{-1}$ ) and B:C ratio (3.41) was recorded with 100 per cent RDF with fertigation in 5 splits as compared to all other treatments (Table 2). This was mainly attributed to significantly higher seed cotton yield as compared to all the other treatments. From the study, it could be inferred that drip fertigation of 100 per cent RDF through WSF recorded higher nitrogen, phosphorus and potash uptake, water use efficiency. But drip fertigation of 100 per cent RDF through NF was economically viable compared to other treatments. Results are in conformity with the finding of Amarananjundeshwara et al. (1999).

\section{Conclusions}

This study has shown that compared to soil application through fertilizers, fertigation treatments increased 10-25 per cent number of leaves plant ${ }^{-1}, 24-36$ per cent total dry matter production plant $^{-1}, 15-39$ per cent number of bolls plant ${ }^{-1}$ and 16-46 per cent seed cotton yield $\mathrm{ha}^{-1}$. Among fertigation treatments, 100 per cent RDF with fertigation in 5 splits recorded significantly higher seed cotton yield (3397 $\left.\mathrm{kg} \mathrm{ha}^{-1}\right)$, increased 45.7 per cent compared to RDF-soil application and 16-35 per cent among other fertigation treatments.

\section{REFERENCES}

[1] PANSE, V.G. AND SUKHATME, P.V., 1967, Statistical methods for Agricultural Workers, ICAR publications, New Delhi, pp. 359.

[2] NALAYINI, P., KANDASAMY, O.S. AND BALASUBRAMANIYAN, A., 2001, Production potential and nitrogen use efficiency of inter-specific and intra-hirsutum cotton hybrids under graded levels of nitrogen and weed-control methods. Indian J. Agron., 46(3): 557-562.

[3] SRINIVASAN, G., 2003, Response of cotton (Gossypium hirsutum) to split application of major nutrients. Indian $J$. Agron., 48(1): 59-61.

[4] BALASUBRAMANIAN, V.S., PALANAIAPPAN, S.P. AND CHELLIAH, S., 2000, Increasing water use efficiency through fertigation in cotton. J. Indian Soc. Cott. Improv., 25: 92-95.

[5] AMARANANJUNDESHWARA, H., KHAN, M.M., KRISHNA, R., KARIYANNA, SREERAMA, R. AND MALLIKARJUNA BIRADAR, 1999, Effect of sources and levels of fertigation on productivity of tomato. In Proc. Natn. Sem. On Problems and Prospectus of micro and Sprinkler Irrig.; A critical Apprisal. held on 19-20, at Bangalore, India. pp. 213 . 